\title{
Social Classes, Level of Education, Marital Status, Alcohol and Tobacco Consumption as Predictors in a Successful Treatment of Obesity
}

\author{
Isaac Kuzmar ${ }^{1 *}$, Maria Mercedes Rizo $^{2}$ and Ernesto Cortes ${ }^{3}$
}

${ }^{1}$ University of Alicante, Spain

${ }^{2}$ Maria Mercedes Rizo University of Alicante, Spain

${ }^{3}$ Ernesto Cortes Miguel Hernández University of Elche, Spain

\begin{abstract}
Objective: To evaluate if there is a relation between social classes, level of education, marital status, alcohol and tobacco consumption with the success of weight loss in obese patients at a nutrition clinic.

Methods: A clinical intervention study was conducted among overweight and obese patients who consulted a nutrition clinic in Barranquilla (Colombia) for the purpose of nutritional assessment. They were subject to a personalized weekly follow-up consultation over the course of 16 weeks in which food consumption patterns, body image and self-perception were registered.

Results: A total of 271 patients were evaluated. $27(10 \%)$ of whom did not complete the study. $244(90 \%)$ patients followed the treatment, $70(28,7 \%)$ didn't lose weight, considering them failures and $174(71,3 \%)$ did lose weight. No considerable differences were observed in relation to social classes, level of education, marital status, alcohol and tobacco consumption in failure-success distribution.

Conclusion: Based on these results, social classes, level of education, marital status, alcohol and tobacco consumption are not regarded as influential factors in the successful outcome of treatment in overweight and obese patients.
\end{abstract}

Keywords: Obesity; Social classes; Marital Status; Alcohol; Tobacco; Predictors; Treatment

\section{Introduction}

Overweight and the obesity represent an increasing threat to the general population in many countries [1], and it is considered to be a worldwide epidemic [2]. Body image and self-perception play an important role in the personal growth and adaptation, as well as children and adolescents [3].

It is extremely important to diagnose and tackle obesity at early stages due to the high risk of cardiovascular events, cancer and the mortality associated [4].

High rates of overweight in adolescence described in many countries [5] could suggest a relation with the energy balance factors involved. Obesity is the result of caloric expenditure failing short of caloric intake. Unhealthy eating habits, the lack of fruits and vegetables in the daily intake, consuming soft drinks and fast food combine with a poor physical activity and exercise are major contributors with the problem [6].

Previous studies have shown the association between the increase of Body Mass Index (BMI) in adolescents coming from poorest regions and the decreased of the BMI in richest regions [7]. Obesity is related to a low level of educational attainment, has been use as a marker of inadequate health [8] and branded as a social phenomenon for which appropriate actions should target cultural and socioeconomic issues.

In regards of marital status, obese wives who do household activities reflect greater insecurity in contrast with those who have a career. They feel less attractive; suffer from physical discomfort or feel of rejection and poor self-esteem [9].

More than half of obese post-menopausal women are living in rural areas with conditions below poverty, less alcohol intake and tobacco consumption as a result of this although they have a greater sedentary lifestyle [10].
Weight loss and dieting are common concerns for both genders, for most of them a diet is about consuming less fat rather than using a combination of lower caloric intake with aerobic exercise [11].

In Colombia to measure population's wealth, the socioeconomic status must be obtained from the amount of monthly services charges as well as tax billing for different areas of the city [12].

The main objective is to determine if there is a relation between social classes, level of education, marital status, and alcohol and tobacco consumption with the success of weight loss in obese patients.

\section{Material and Methods}

\section{Subjects}

A clinical intervention study was conducted among overweight and obese patients who consulted a nutrition clinic in Barranquilla (Colombia) for the purpose of nutritional assessment. They were subject to a personalized weekly follow-up consultation over the course of 16 weeks in which food consumption patterns, body image and self-perception were registered. The inclusion criteria were voluntary assistance, patient desire to improve their aesthetic image, excluding those with chronic diseases such as diabetes, kidney failure, etc., 233 women and 38 men were interviewed.

*Corresponding author: Isaac Kuzmar, University of Alicante, San Vicente de Raspeig, Alicante, Spain, Tel: 34659926253; E-mail: isaackuzmar@yahoo.es

Received February 25, 2014; Accepted March 03, 2014; Published March 31, 2014

Citation: Kuzmar I, Rizo MM, Cortes E (2014) Social Classes, Level of Education, Marital Status, Alcohol and Tobacco Consumption as Predictors in a Successful Treatment of Obesity. J Nutr Disorders Ther 4: 135. doi:10.4172/21610509.1000135

Copyright: @ 2014 Kuzmar I, et al. This is an open-access article distributed unde the terms of the Creative Commons Attribution License, which permits unrestricted use, distribution, and reproduction in any medium, provided the original author and source are credited. 


\section{Methodology}

The study used data of patients who consulted a nutrition medical centre in Barranquilla (Colombia) for nutritional assessment and to improve their physical appearance, which underwent a low-calorie personalized diet nutritional health program by food consumption patterns, over the course of 16 consecutive weeks. The sample was formed by patients from 16 to 72 years of age collected over a period of 3 years.

The study included, an initial complete medical record (date accessed, date of birth, personal identification data, socioeconomic status, educational level, marital status and personal medical history, toxic precedents, etc.) and a weekly medical-nutritional assessment (age, height and weight, waist and hip perimeter, and one photography)

The data were treated using IBM SPSS Statistics version 22.0 software, checking the normality and comparative nonparametric statistics on data that not showed a normal distribution. The multivariate linear correlation was performed to the dependent variable percentage of weight loss regarded to social status, educational level, marital status, alcohol and tobacco consumption. The distributions were analysed using the Chi square test with Epidat version 3.1 software. A significance level of $\mathrm{p}<0,05$ is considered.

\section{Results}

A total of 271 patients were evaluated $27(10 \%)$ of whom did not complete the study. 244 (90\%) patients followed the treatment of whom $174(71,3 \%)$ were successful and $70(28,7 \%)$ failed.

In regards of marital status, $102(68,9 \%)$ singles are successful, opposite to $72(58,5 \%)$ who are married or live in couples, but this major success among singles is not significant. 28 (68,3\%)success medium class is obtained in opposite to $146(63,5 \%)$ in high class, not presenting a different significantly distribution either. 141 (68.8\%) high school graduates presents a success compared to $33(50,0 \%)$ university students, the distribution is significantly different $(p=0,020)$ (Table 1$)$. Finally, between tobacco consuming, a success is obtained in $36(65,5 \%)$ compared to $138(63,9 \%)$ who did not consume, not being statistically significant; and those with alcohol consumption, a success is obtained in $102(60,4 \%)$ compared to $72(68,6 \%)$ without statistical significance.

In order to avoid interference between the studied variables, the multinomial regression analysis was performed in dropouts against success and failure versus success regarding social classes, level of education, marital status, and alcohol and tobacco consumption. The results are presented in Table 2 and Table 3 respectively.

Weight loss percentage was $2,7 \%(\mathrm{SD}=1,2)$, from an initial $\mathrm{BMI}$ of $27,0 \mathrm{~kg} / \mathrm{m}^{2}(\mathrm{SD}=3,5)$ to a loss of $0,7 \mathrm{BMI} \mathrm{kg} / \mathrm{m}^{2}(\mathrm{SD}=0,3)$.

\section{Discussion}

The present study has used a non-invasive clinical approach and has searched if five factors can be determinants in the success of a treatment for obesity in a Caribbean population. Patients who completed treatment and therefore have lost weight in the four months are $64,2 \%$ of the total that looked at first, and $71,3 \%$ of the total that began the treatment, despite the great difficulties that arise in the treatment of overweight and obesity. The dropout rate is small maybe, because the initial attendance is voluntary and for aesthetic reasons without a clinical condition. Moreover, the treatment must be performed moderately and continuously in order to avoid dropout and recovery of the initial weight.

\begin{tabular}{|c|c|c|c|c|c|}
\hline & & dropouts & failure & success & $\begin{array}{l}\text { Chi square } \\
\text { test }\end{array}$ \\
\hline \multirow{2}{*}{ marital status } & single & 10 & 36 & 102 & \multirow{2}{*}{ ns } \\
\hline & married/ couple & 17 & 34 & 72 & \\
\hline \multirow{2}{*}{ socialclasses } & medium & 3 & 10 & 28 & \multirow{2}{*}{ ns } \\
\hline & high & 24 & 60 & 146 & \\
\hline \multirow{2}{*}{$\begin{array}{l}\text { educational } \\
\text { level }\end{array}$} & high school graduate & 17 & 47 & 141 & \multirow{2}{*}{0,020} \\
\hline & university & 10 & 23 & 33 & \\
\hline \multirow{2}{*}{$\begin{array}{l}\text { tobacco } \\
\text { consumption }\end{array}$} & yes & 5 & 14 & 36 & \multirow{2}{*}{ ns } \\
\hline & no & 22 & 56 & 138 & \\
\hline \multirow{2}{*}{$\begin{array}{l}\text { Alcohol } \\
\text { consumption }\end{array}$} & yes & 15 & 52 & 102 & \multirow{2}{*}{ ns } \\
\hline & no & 12 & 18 & 72 & \\
\hline
\end{tabular}

Table 1: Distribution of success and failure in regard of marital status, social classes, educational level and consumption of alcohol and tobacco.

\begin{tabular}{|l|l|l|}
\hline Success vs. dropouts & Sig. & OR (CI 95\%) \\
\hline single vs. married (couple) & 0,105 & $0,5(0,2-1,2)$ \\
\hline social classes medium vs high & 0,867 & $0,9(0,2-3,3)$ \\
\hline high school vs. university & 0,113 & $0,5(0,2-1,2)$ \\
\hline tobacco consumption vs. no consumption & 0,985 & $1,0(0,3-2,9)$ \\
\hline alcohol consumption vs. no consumption & 0,417 & $0,7(0,3-1,7)$ \\
\hline
\end{tabular}

Table 2: Multinomial regression analysis to dropouts versus successful weight loss in relation to marital status, social classes, educational level and alcohol and tobacco consumption.

\begin{tabular}{|l|l|l|}
\hline success vs. failure & Sig. & OR (CI 95\%) \\
\hline Single vs. married (couple) & 0,812 & $0,9(0,5-1,7)$ \\
\hline social class medium vs. high & 0,963 & $1,0(0,4-2,2)$ \\
\hline high school graduate vs. university & 0,096 & $0,6(0,3-1,1)$ \\
\hline tobacco consumption vs. no consumption & 0,593 & $0,8(0,4-1,7)$ \\
\hline alcohol consumption vs. no consumption & 0,056 & $1,9(1,0-3,6)$ \\
\hline
\end{tabular}

Table 3: Multinomial regression analysis to failure versus successful weight loss in relation to marital status, social classes level of education and alcohol and tobacco consumption.

In this study there is stated a discreet percentage of weight loss with treatment adherence, and patients were satisfied with their new body image comparing previous and post-treatment photographies.

Numerous studies state that low class linked to a low level of education develops obesity [13], likewise, they indicate that obesity is less common in singles [14]; but the present results demonstrate that this condition does not affect the treatment success. It is necessary to bear in mind that the studied population was medium and high class [15], and, like other studies, obesity no longer depends on the economic income [16].

World population tends to overweight and obesity due to current lifestyle [17], nevertheless, a personalized diet improves the pathological condition of the patients [18], being very important to perform previous surveys that lead to treatment success [19].

It is known that smoking [20] and alcohol consumption [21] associated with obesity, increased cardiovascular risk, but as observed in the present study, did not appear to influence the treatment success, not perceiving greater awareness among consumers, although one of the nutritional advice in cases of regular alcohol consumption is precisely to stop it, because the extra intake of calories with no nutritional sense.

\section{Conclusion}

From the study we could suggest that in regards to the correct design of a 16 weeks follow up weight loss program directed to obesity in Colombia, the program has to be designed individually and 
Citation: Kuzmar I, Rizo MM, Cortes E (2014) Social Classes, Level of Education, Marital Status, Alcohol and Tobacco Consumption as Predictors in a Successful Treatment of Obesity. J Nutr Disorders Ther 4: 135. doi:10.4172/2161- 0509.1000135

consider factors such a dietary changes based on patients food choices and preferences, without taking into account social classes, level of education, marital status, alcohol and tobacco consumption which are not proven to be influential factors in the successful outcome in overweight and obese patients.

\section{References}

1. (2000) Obesity: preventing and managing the global epidemic. Report of a WHO consultation. World Health Organ Tech Rep Ser 894: 1-253.

2. Gesta S, Tseng YH, Kahn CR (2007) Developmental origin of fat: tracking obesity to its source. Cell 131: 242-256.

3. LameirasFernández $\mathrm{M}$, Calado Otero $\mathrm{M}$, Rodríguez Castro $\mathrm{Y}$, FernándezPrieto M (2002) [Eating disorders among Spanish university students]. Actas Esp Psiquiatr 30: 343-349.

4. Garrow J (1991) Importance of obesity. BMJ 303: 704-706.

5. Flegal KM (1999) The obesity epidemic in children and adults: current evidence and research issues. Med Sci Sports Exerc 31: S509-514.

6. Centers for Disease Control and Prevention. (dec de 2013). . Report of the National Center for Chronic Disease Prevention and Health Promotion. Physical Activity and Good Nutrition: Essential Elements for Good Health. Ataglance 2010. Obtenido de.

7. da Veiga GV, da Cunha AS, Sichieri R (2004) Trends in overweight among adolescents living in the poorest and richest regions of Brazil. Am J Public Health 94: 1544-1548.

8. Garcinuño AC, López SA, Alonso IC, García IP (2010) [Social disparities in the prevalence of overweight and obesity in adolescents]. An Pediatr (Barc) 73: $241-248$

9. Benítez Guerrero V, Castillo Torres L, Escalante y García S, Rea Rodríguez C (2009) La obesidad, unproblema de salud y suinfluencia en lasrelaciones de pareja. Rev Cientif Electron Psicol, (7): 87-96.

10. Navarro Rodríguez MC, Saavedra Santana $P$, de Pablos Velasco $P$, Sablón González N, de Miguel Ruiz E, et al. (2009) [Lifestyle, socioeconomic status and morbidity in postmenopausal women with grade II and III obesity] Endocrinol Nutr 56: 227-232.

11. Serdula MK, Mokdad AH, Williamson DF, Galuska DA, Mendlein JM, et al. (1999) Prevalence of attempting weight loss and strategies for controlling weight. JAMA 282: 1353-1358.

12. Dane (2014) La estratificaciónsocioeconómica en el régimen de los serviciospúblicosdomiciliarios. Recuperado el 17 de Febrero de 2014, de

13. Aranceta-Bartrina J, Pérez-Rodrigo C, Ribas-Barba L, Serra-Majem L (2005) Epidemiología y factoresdeterminantes de la obesidadinfantil y juvenil en España. Rev PediatrAtenPrimaria, 7: 13-20.

14. Gutiérrez-Fisac JL (202) Epidemiología de la obesidad. Jano 63: 35-36.

15. McLaren L (2007) Socioeconomic status and obesity. Epidemiol Rev 29: 29-48.

16. Shajithanoop S, Palanivelu C, Senthilnathan P (2013) A Pilot Study on Predictive Factors for Over Weight and Obesity in School. J Nutr Disorders Ther 1-4.

17. Centers for Disease Control, National Center for Chronic Disease Prevention and Health Promotion. (Oct-Dec de 2003). Physical activity and good nutrition: essential elements to prevent chronic diseases and obesity 2003. Nutr Clin Care 6: 135-138.

18. Velázquez-López L, Sil-Acosta MJ, Goycochea-Robles MV, Escobedo-De la Peña J, Castañeda-Limones R (2008) [Effect of a personalized diet in the metabolic control and renal function of patients with type 2 diabetes]. Rev Med Inst Mex Seguro Soc 46: 11-18.

19. Kruger J, Yore MM, Bauer DR, Kohl HW (2007) Selected barriers and incentives for worksite health promotion services and policies. Am J Health Promot 21: 439-447.

20. Velázquez Monroy $O$, Rosas Peralta $M$, Lara Esqueda A, Pastelín Hernández G, Attie F, et al. (2002) [Arterial hypertension in Mexico: results of the National Health Survey 2000]. Arch Cardiol Mex 72: 71-84.

21. Figueroa-López CG, Ramos del Río B (2011) Factores de riesgo de la hipertensión arterial y la salud cardiovascular en estudiantesuniversitarios. An Psicol 27: 739-744. 